\title{
Sonological evaluation of male infertility at tertiary care hospital
}

\author{
Umashankar KM, Jayeeta Mukerjee, BN Seal, SN Banerjee, Rizval Karim \\ Correspondence: Umashankar KM, Assistant Professor, Department of Obstetrics and \\ Gynaecology, BMCRI, Bangalore, Karnataka, India; Email- ukumashankar@gmail.com
}

Distributed under Creative Commons Attribution-Share Alike 4.0 International.

\begin{abstract}
Objectives: The aim of the study was to sonological evaluation of male infertility at pre-testicular, testicular and post-testicular levels. Material and methods: This study was conducted in the department of obstetrics and gynecology in collaboration with the department of radiodiagnosis. All the patients are evaluated with history, clinical examination, and appropriate basic investigations like semen analysis. Patients are classified into pretesticular, testicular, post-testicular and idiopathic groups. Trans scrotal ultrasound (TSU) and doppler, trans rectal ultrasound (TRUS) were done. The observations are tabulated and analyzed. Results: The TRUS findings in the testicular group 2 numbers of patients had calcification of prostrate. In post testicular group $82.3 \%(n=14)$ had seminal vesicle enlargement, $47 \%(n=8)$ had ejaculatory duct enlargement. In the idiopathic group $60 \%$ $(n=3)$ had seminal vesicle cyst, $20 \%(n=1)$ had enlarged prostate and $20 \%(n=1)$ had seminal vesicle calcification. The TSU findings in the testicular group $66.6 \%(\mathrm{n}=14)$ had small testis, 33.33\% $(\mathrm{n}=7)$ patients had calcification, $30.0 \%(n=8)$ had varicocele of testis. In post testicular group epididymal cyst seen in $50 \%(n=8)$, epididymal calcification in $31.2 \%(n=5)$. In idiopathic group epididymal cyst seen in $22.2 \%(n=2)$, epididymal calcification in $22.2 \%(n=2)$. Conclusion: Imaging modalities are adjuvant to conventional evaluation of male infertility whereas the imaging modalities evaluate the anatomical integrity and normalcy of male reproductive system.
\end{abstract}

Keywords: TRUS, sonological, male infertility.

Imaging modalities are the third eye of clinician in modern medical analysis. They are useful in providing the anatomical reason for an abnormal physiology. They enhance the sensitivity and specificity of clinical examination. In male infertility evaluation, they are provided abnormal anatomical morphology which may be the cause for pathological seminogram ${ }^{1-3}$. They also help in planning any corrective surgeries. Internal male reproductive tract assessment by clinician is less sensitive and less specific. TRUS evaluates prostrate, seminal vesicles, ducts. TSU evaluates pampiniform plexus, intra testicular mass. Doppler evaluates the blood flow to testis. Thus they help in accurate diagnosis and appropriate management of male infertility. The review of literature reveled even with the advances in the medical technology, many of the causes of male infertility remains unknown, this lacunae of understanding the etiopathogenesis has stagnated the growth in treatment strategies ${ }^{4}$. This study attempts to evaluate male infertility patients by use TRUS, TSU and trans scrotal Doppler.

Received: $9^{\text {th }}$ January 2018. Accepted: $26^{\text {th }}$ April 2018.

Umashankar KM, Mukerjee J, Seal BN, Banerjee SN, Karim R. Sonological evaluation of male infertility at tertiary care hospital. The New Indian Journal of OBGYN. 2018; 5(1): 47-50. 
The New Indian Journal of OBGYN. 2018 (July - December); 5(1)

\section{Materials and Methods}

This study was conducted in the department of Obstetrics and Gynecology in collaboration with the department of Radiodiagnosis, Institute of Postgraduate Medical Education and Research, and S.S.K.M. hospital, Kolkata from 01-08-2009
Table 1: Distribution of normal TRUS and TSU findings in various groups of infertility $(\mathrm{N}=100)$

\begin{tabular}{cccc} 
Categories & $\begin{array}{c}\text { No of } \\
\text { cases }\end{array}$ & $\begin{array}{c}\text { Cases having normal } \\
\text { findings in TRUS } \\
\text { Number }(\%)\end{array}$ & $\begin{array}{c}\text { Cases having normal } \\
\text { findings in TSU } \\
\text { Number }(\%)\end{array}$ \\
\hline Pre-testicular & 7 & $7(100 \%)$ & $7(100 \%)$ \\
Testicular & 27 & $25(92.5 \%)$ & $6(10.4 \%)$ \\
Post-testicular & 27 & $10(37 \%)$ & $11(40.7 \%)$ \\
Idiopathic & 39 & $34(87.1 \%)$ & $30(76.9 \%)$ \\
\hline
\end{tabular}

to 31-07-2010. Male patients attending infertility clinic, outpatient for treatment of infertility, and those who have abnormal semen analysis were taken. Total 100 numbers of patients were studied. All the patients are evaluated with history, clinical examination, and appropriate basic investigations like semen analysis. All patients should have at least two or three semen analyses (American Urologic Association and the American Society of Reproductive Medicine, 2001). Most specimens were obtained by masturbation. The specimen was examined in the laboratory within 1 to 2 hours of collection. The measurement of follicle stimulating hormone (FSH), leutenizing hormone (LH), thyroid stimulating hormone (TSH), and prolactin were done based on the seminogram report. The patients were classified into pre-testicular, testicular, post-testicular and idiopathic groups. Those with abnormal semen analysis and those with unexplained infertility were subjected to non invasive imaging modalities. Tran's scrotal ultrasound [Model TOSHIBA MAKE XARIO, Linear probe $12 \mathrm{MHz}$ ] and Trans scrotal Doppler, Trans rectal ultrasound (Model TOSHIBA MAKE XARIO, Tran's rectal probe $10 \mathrm{MHz}$ ) were done. The observations are tabulated and analyzed.

\section{Results}

In this study TRUS showed normal study in $100 \%$ $(\mathrm{N}=7)$ pre-testicular cases, $92.5 \%(\mathrm{~N}=25)$ testicular cases, $37 \%(\mathrm{~N}=10)$ post-testicular cases and $87.1 \%(\mathrm{~N}=34)$ idiopathic cases. Trans scrotal ultrasound showed normal study in $100 \%(\mathrm{~N}=7)$ pre-testicular cases, $10.4 \%(\mathrm{~N}=11)$ of testicular cases, $40.7 \%(\mathrm{n}=11)$ of post-testicular cases and $76.9 \%(n=30)$ of idiopathic cases (Table 1). In this study there is no abnormality in the TRUS findings in the pre testicular patient's. In the testicular group 2 numbers of patients had calcification of prostrate. In the post testicular group $82.3 \% \quad(\mathrm{n}=14)$ had seminal vesicle enlargement, $47 \% \quad(\mathrm{n}=8)$ had ejaculatory duct enlargement, $18.5 \%(\mathrm{n}=5)$ patients had midline cysts,

seminal vesicle cyst in $14.8 \%(\mathrm{n}=4)$ of patients. In the idiopathic group $60 \%(\mathrm{n}=3)$ had seminal vesicle cyst, $20 \%$ $(n=1)$ had enlarged prostrate. $20 \%(n=1)$ had seminal vesicle calcification. In the post testicular group each

Table 2: Abnormal TRUS findings in various groups of infertility

\begin{tabular}{ccc}
\hline Categories & $\begin{array}{c}\text { Type of } \\
\text { abnormalities }\end{array}$ & $\begin{array}{c}\text { Number } \\
\mathbf{( \% )}\end{array}$ \\
\hline $\begin{array}{c}\text { Pre-testicular } \\
\text { group }(\mathrm{N}=0)\end{array}$ & - & - \\
Testicular group & Calcification of & \\
pros) & prostate & $2(100 \%)$ \\
Post-testicular & Seminal vesicle & \\
group $(\mathrm{N}=17)$ & enlarged & $14(82.3 \%)$ \\
& Ejaculatory duct & \\
& enlargement & $8(47 \%)$ \\
& Mid line cyst & $5(18.5 \%)$ \\
Idiopathic group & Seminal vesicle cyst & $4(14.8 \%)$ \\
$(\mathrm{N}=5)$ & Seminal vesicle cyst & $3(60 \%)$ \\
& Enlarged prostrate & $1(20 \%)$ \\
& Seminal vesicle & \\
& calcification & $1(20 \%)$ \\
\hline
\end{tabular}

patient had more than one abnormal finding. This explains the discrepancy in column percentages (Table 2). In this study there were no abnormalities in the TSU findings in the pre-testicular patients. In the testicular group $66.6 \%$ $(n=14)$ had small testis, $4.7 \%(n=1)$ had absent testis, $33.33 \%(\mathrm{n}=7)$ patients had calcification of testis, 30.0\% $(n=8)$ had varicocele, $9.5 \%(n=2)$ of the patients had avulsion of testis. In post-testicular group epididymal cyst seen in $50 \%(\mathrm{n}=8)$, epididymal calcification in $31.2 \%$ $(\mathrm{n}=5), 12.5 \%$ of patients had thickened epididymis, $12.5 \%$ of patients had an echoic lesion, $6.2 \%$ of the patients had fluid around the testis. In idiopathic group, epididymal cyst seen in $22.2 \%(\mathrm{n}=2)$, epididymal calcification in $22.2 \%(\mathrm{n}=2), 22.2 \%$ of patients had testicular cyst, $11.1 \%$ $(n=1)$ had small testis, $22.2 \%(n=2)$ had testicular 
Table 3: Distribution of abnormal TSU findings in various groups

\begin{tabular}{|c|c|c|}
\hline Categories & $\begin{array}{c}\text { Type of } \\
\text { abnormalities }\end{array}$ & Number (\%) \\
\hline $\begin{array}{l}\text { Pre-testicular } \\
\text { group }(\mathrm{N}=0)\end{array}$ & - & - \\
\hline \multirow{8}{*}{$\begin{array}{c}\text { Testicular } \\
\text { group }(\mathrm{N}=21)\end{array}$} & Small testis & $14(66.66 \%)$ \\
\hline & U/L non & \\
\hline & $\begin{array}{c}\text { visualization of } \\
\text { testis }\end{array}$ & $1(4.7 \%)$ \\
\hline & Testicular & \\
\hline & calcification & $7(33.3 \%)$ \\
\hline & Anechoic lesion & $1(4.7 \%)$ \\
\hline & Varicocele & $8(38.09 \%)$ \\
\hline & $\begin{array}{l}\text { Avulsion of } \\
\text { epididymis }\end{array}$ & $2(9.5 \%)$ \\
\hline \multirow{6}{*}{$\begin{array}{l}\text { Post-testicular } \\
\text { group }(\mathrm{N}=16)\end{array}$} & Epididymal cyst & $8(50 \%)$ \\
\hline & $\begin{array}{l}\text { Epididymal } \\
\text { calcification }\end{array}$ & $5(31.2 \%)$ \\
\hline & $\begin{array}{l}\text { Thickened } \\
\text { epididymis }\end{array}$ & $2(12.5 \%)$ \\
\hline & Anechoic lesion & $2(12.5 \%)$ \\
\hline & $\begin{array}{l}\text { Fluid around the } \\
\text { testis }\end{array}$ & $1(6.2 \%)$ \\
\hline & Vas dilated & $4(25 \%)$ \\
\hline \multirow{8}{*}{$\begin{array}{c}\text { Idiopathic } \\
\text { group }(\mathrm{N}=9)\end{array}$} & Epididymal cyst & $2(22.2 \%)$ \\
\hline & Testicular cyst & $2(22.2 \%)$ \\
\hline & Small testis & $1(11.1 \%)$ \\
\hline & Epididymal & \\
\hline & $\begin{array}{l}\text { calcitication } \\
\text { U/L non }\end{array}$ & $2(22)$ \\
\hline & $\begin{array}{l}\text { visualization of } \\
\text { testis }\end{array}$ & $2(22.2 \%)$ \\
\hline & Testicular & \\
\hline & calcification & $2(22.2 \%)$ \\
\hline
\end{tabular}

Table 4: Distribution of abnormal scrotal doppler findings in various groups

\begin{tabular}{|c|c|c|}
\hline Categories & Doppler findings & Number (\%) \\
\hline $\begin{array}{l}\text { Pre-testicular } \\
\text { group }(\mathrm{N}=1)\end{array}$ & $\begin{array}{l}\text { Central flow reduced } \\
\text { with peripheral flow } \\
\text { increased }\end{array}$ & $1(100 \%)$ \\
\hline $\begin{array}{l}\text { Testicular group } \\
(\mathrm{N}=6)\end{array}$ & $\begin{array}{l}\text { Central flow reduced } \\
\text { with peripheral flow } \\
\text { increased } \\
\text { Non pulsatile flow }\end{array}$ & $\begin{array}{l}1(16.6 \%) \\
5(83.3 \%)\end{array}$ \\
\hline $\begin{array}{l}\text { Post-testicular } \\
\text { group }(\mathrm{N}=0) \\
\text { Idiopathic group } \\
(\mathrm{N}=1)\end{array}$ & $\begin{array}{l}\text { - } \\
\text { Central flow reduced } \\
\text { with peripheral flow } \\
\text { increased }\end{array}$ & $1(100 \%)$ \\
\hline
\end{tabular}

calcification, $22.2 \%(\mathrm{n}=2)$ had absent testis. In this study each patient had more than one abnormal finding. This explains the discrepancy in column percentages (Table 3).

In this study trans-scrotal doppler showed normal study in $85.7 \%(\mathrm{n}=6)$ pre-testicular cases, $77.7 \%(\mathrm{n}=21)$ of testicular cases, $100 \%(n=27)$ of post-testicular cases and $97.4 \%(n=38)$ of idiopathic cases. Reduced central flow with increase peripheral flow seen in $100 \%(n=1)$ in pre-testicular group, $16.6 \%(\mathrm{n}=1)$ in testicular group and $100 \%(n=1)$ in idiopathic group. In testicular group $83.3 \%$ of patients had non pulsatile flow.

\section{Discussion}

In this study TRUS showed normal study in $100 \%$ pretesticular cases, $92.5 \%$ testicular cases, $37 \%$ post testicular cases and $87.1 \%$ idiopathic cases. Vignera also observed similar normal TRUS in pre-testicular cases. ${ }^{5}$

In this study there were no abnormalities in the TRUS findings in the pre-testicular patient's. In the testicular group two patients had calcification of prostrate that accounted for $100 \%$ abnormality in this group. TRUS is the initial investigation tool used to locate and visualize the presence of calcifications that may contribute to the obstruction $^{6}$.

In the post-testicular TRUS group $82.3 \%$ had seminal vesicle enlargement, $47 \%$ had ejaculatory duct enlargement, and $18.5 \%$ patients had midline cysts, seminal vesicle cyst in $14.8 \%$ of patients. In the post testicular group each patient had more than one abnormal finding. This explains the discrepancy in percentages. In the idiopathic group $60 \%$ had seminal vesicle cyst, $20 \%$ had enlarged prostrate. Study conducted by $\mathrm{Xu}$ Chen et $\mathrm{al}^{7}$ with TRUS found that obstructive azoospermia is one of the common causes of male infertility. In this study, it was observed that dilatation of ejaculatory duct $(29 \%$, 374/1249) was the most common cause of obstructive azoospermia, followed by seminal vesicle abnormalities $(28.5 \%, 356 / 1249)$. The study conducted by Vignera was found congenital absence of vas in $34 \%$, bilateral ductal occlusion by fibrosis $16 \%$,congenital unilateral absence of vas $11 \%$, obstructing cysts in ductal system $9 \%$, ductal obstruction due to calculi $4 \%{ }^{1}$

Scrotal US is considered the primary imaging modality for the evaluation of scrotal abnormalities ${ }^{6,8}$. Scrotal US can be helpful in determining whether 
azoospermia is non-obstructive or obstructive, because it can directly detect abnormalities in the testis, mediastinum testis, epididymis, and the proximal vas deferens. In this study Tran's scrotal ultrasound showed normal study in $100 \%$ pre-testicular cases, $10.4 \%$ of testicular cases, $40.7 \%$ of post testicular cases and $76.9 \%$ of idiopathic cases. In the testicular group $66.6 \%$ had small testis, $4.7 \%$ had absent testis, $33.33 \%$ patients had calcification of testis, $30.0 \%$ had varicocele, $9.5 \%$ of the patients had avulsion of testis and $4.7 \%$ of the patient had anechoic lesion in the testis. Evaluation of testicular volume with scrotal US are helpful in differentiating obstructive from nonobstructive azoospermia in infertile men. Testicular volume measured is higher for obstructive azoospermia than for nonobstructive azoospermia ${ }^{9}$. Cocuzza $\mathrm{M}$ et al ${ }^{10}$ mention in their study that Varicoceles are the most dominant physical finding in infertile men; indeed, they may be responsible for nearly one-third of cases of male infertility.

\section{Conclusion}

Evaluation of infertile men thoroughly is mandatory to identify the patient with potentially correctable pathology such as obstructive from nonobstructive azoospermia to eliminate unnecessary investigations and interventions.

\section{Conflict of interest: None. Disclaimer: Nil.}

\section{References}

1)Sabra SM, Al-Harbi MS. An influential relationship of seminal fluid microbial infections and infertility, Taif Region, KSA. World J Med Sci. 2014; 10: 32-7.

2)Wamoto TI, Nozawa S, Yoshiike M. Semen quality of Asian men. Reprod Med Biol. 2007; 6: 185-93.
3)Ammar T, Sidhu PS, Wilkins CJ. Male infertility: the role of imaging in diagnosis and management, Br J Radiol. 2012; 85: S59-S68.

4)Edey AJ, Sidhu PS. Male infertility: role of imaging in the diagnosis and management. Imaging . 2008; 20: 139-46.

5)Vignera SL. Transrectal ultrasonography in infertile patients with persistently elevated bacteriospermia. Asian Journal of Andrology. 2008; 10(5): 731-40.

6)Joshi M. Role of ultrasound in assessment of male infertility. Biomed Imaging Interv J. 2007; 3: e12-e47.

7)Chen $\mathrm{X}$, Wang $\mathrm{H}$, Wu RP, Liang $\mathrm{H}$, et al. The performance of transrectal ultrasound in the diagnosis of seminal vesicle defects: a comparison with magnetic resonance imaging. Asian J Androl. 2014; 16(6): 907-11.

8)Schurich M, Aigner F, Frauscher F, Pallwein L. The role of ultrasound in assessment of male fertility. Eur J Obstet Gynecol Reprod Biol. 2009 May; 144( Suppl 1): S192-8.

9)Moon MH, Kim SH, Cho JY, Seo JT, Chun YK. Scrotal US for evaluation of infertile men with azoospermia. Radiology. 2006 Apr; 239(1):168-73.

10)Trum JW, Gubler FM, Laan R, van der Veen F. The value of palpation, varicoscreen contact thermography and colour Doppler ultrasound in the diagnosis of varicocele. Hum Reprod. 1996 Jun; 11(6): 1232-35.

\section{Umashankar KM ${ }^{1}$, Jayeeta Mukerjee ${ }^{2}$, BN Seal ${ }^{3}$, SN Banerjee ${ }^{4}$, Rizval Karim ${ }^{5}$}

${ }^{1}$ Assistant Professor, Department of Obstetrics and Gynaecology, BMCRI, Bangalore, Karnataka, India; ${ }^{2}$ RMO Clinical Tutor, OBG, JNM Hospital, Kalayan; ${ }^{3}$ Professor, OBG, IPGMER, Kolkata; ${ }^{4}$ Associate Professor, OBG, IPGMER, Kolkata. 